Article

\title{
Twist and miR-34a Are Involved in the Generation of Tumor-Educated Myeloid-Derived Suppressor Cells
}

Xin Wang ${ }^{1,2, \dagger}$, Xusheng Chang ${ }^{3, \dagger}$, Guangzuan Zhuo ${ }^{4, \dagger}$, Mingjuan Sun ${ }^{5, *}$ and Kai Yin ${ }^{1, *}$

1 Department of General Surgery, Changhai Hospital, the Second Military Medical University, Shanghai 200433, China; E-Mail: wang_x306@126.com

2 Department of Gynaecology and Obstetrics, the 306 Hospital of PLA, Beijing 100037, China

3 Department of General Surgery, Yancheng City First People's Hospital, Yancheng City 224000, Jiangsu, China; E-Mail: changxush163@163.com

4 Department of Colorectal Surgery, the Second Artillery General Hospital of PLA, Beijing 10008, China; E-Mail: zhuoguangzan163@163.com

5 Department of Biochemistry and Molecular Biology, Second Military Medical University, Shanghai 200433, China

$\dagger$ These authors contributed equally to this work.

* Authors to whom correspondence should be addressed; E-Mails: sunmj@smmu.edu.cn (M.S.); kaiyin68@yahoo.com (K.Y.); Tel./Fax: +86-21-8187-1114 (M.S. \& K.Y.).

Received: 7 July 2013; in revised form: 19 September 2013 / Accepted: 23 September 2013 / Published: 14 October 2013

Abstract: Tumors can induce the generation and accumulation of immunosuppressive cells such as myeloid-derived suppressor cells in the tumor microenvironment, contributing to tumor immunological escapes. Many studies have demonstrated that multiple factors could induce myeloid precursor cells into myeloid-derived suppressor cells, not dendritic cells. In our study, we found that tumor supernatants could induce the generation of myeloid-derived suppressor cells by disturbing the development of dendritic cells. Twist and miR-34a may regulate the effect of tumor cells inducing myeloid-derived suppressor cells via TGF- $\beta$ and/or IL-10.

Keywords: myeloid-derived suppressor cells; twist; miR-34a; dendritic cells; tumor escape 


\section{Introduction}

The tumor microenvironment is well known to be immunosuppressive [1-4]. Tumor-derived factors such as TGF- $\beta$, VEGF, IL-10, and $\mathrm{PGE}_{2}$ and other factors such as gangliosides and lactate have been verified to be able to regulate differentiation and function of dendritic cells (DC) and T cells [5-7]. It has been well established that the tumor microenvironment could drive imDC (immature dendritic cells) to differentiate into $\mathrm{CD} 11 \mathrm{~b}^{\text {high }} \mathrm{Ia}^{\text {low }}$ regulatory $\mathrm{DC}$ via $\mathrm{TGF}-\beta$ and $\mathrm{PGE}_{2}$, and that regulatory DC suppress $\mathrm{T}$ cells response [8]. Interestingly, the development of DC could be disturbed in the early period. Myeloid precursor cells may differentiate into DC, macrophages, granulocytes and mast cells depending on the microenvironmental conditions. They might also stay in non-differentiated mixed form, which include myeloid-derived suppressor cells (MDSC) $[9,10]$.

MDSC and DC share the same myeloid precursor cell, and play very different roles in the immune response. MDSC represent a mixed population of immature myeloid cells including DC precursors, and were firstly found in tumor tissues and in the lymph nodes of tumor-bearing mice [11]. It is known that proinflammatory cytokines, such as IL-1 $\beta$, IL- 6 and bioactive lipid PGE 2 could induce the accumulation of MDSC.

MDSC can suppress the immune response via arginase, iNOS [12,13], ROS [14-21], and Foxp3 ${ }^{+}$ regulatory cells [22,23]. DC showed a capacity to initiate innate and adaptive response [24-27] and $\mathrm{DC}$ can induce $\mathrm{T}$ cell immune response by presenting the foreign antigen, upregulating co-stimulatory molecules and releasing proinflammatory cytokines. And in the tumor microenvironment, regulatory DC suppress T cells function via arginase I [8]. It should be noted that regulatory DC (regDC) are very different from conventional DC, and regDC derived from different organ stromal microenvironments are generated through different mechanisms.

Twist is a transcription factor that belongs to the bHLH family and expressed in and associated with many types of aggressive tumors, including breast cancer [28], hepatocellular carcinoma [29,30], prostate cancer [31,32], oesophageal squamous cell carcinoma [33,34], bladder cancer [35,36] and pancreatic cancer [37]. Twist plays multiple roles in cancer initiation, progression and metastasis [38]. More specifically, Twist can override oncogene-induced cell senescence and apoptosis, increase cancer cell resistance to chemotherapy, enhance cancer stem cell (CSC) population, and facilitate cancer cell invasion and metastasis [38]. So, we guessed that Twist may increase the population of MDSC or enhance the capacity of MDSC.

MicroRNA (miRNAs) are a conserved class of non-coding 20-22 nt small RNAs that regulate gene expression by binding to mRNA, leading to mRNA degradation or inhibition [39]. And a global decrease in microRNA (miRNA) levels is often observed in human cancer [40], indicating that small RNAs may have an intrinsic function in tumor suppression. MicroRNA miR-34 was fully studied and was identified as a p53 target and a potential tumor suppressor [40-43]; miR-34 may also act in concert with other effectors to inhibit inappropriate cell proliferation.

In our research, we tried to test whether tumor supernatant could induce myeloid precursor cells into MDSC, not DC, and elucidated the roles of Twist and miR-34a in the process. We hope that this research may provide a new understanding of the mechanism of tumor immune escape. 


\section{Results and Discussion}

\subsection{Tumor Culture Supernatants Disturb the Development of the Bone Marrow-Derived Dendritic Cell}

Bone marrow-derived dendritic cells were produced by standard protocol in vitro, and the process of transduction from myeloid precursors into DC needs 5 or 6 days [44-46]. Myeloid precursor cells washed from mice bone marrow were co-cultured with NIH3T3, Hepa1-6, and CT26 cell lines supernatants as the method indicated.

Figure 1. Tumor supernatants pretreated cells showed an altered phenotype and cytokine profile, and a reduced ability to stimulate proliferation of $\mathrm{T}$ cells. Myeloid precursor cells were generated from mice (BALB/c mice, 5-6 weeks of age) femur bone marrow suspensions by depletion of red cells. These cells were cultured in 24 well plates using $1 \times 10^{6}$ cell/well. All groups were cultured with GM-CSF, IL-4 during the entire process. $24 \mathrm{~h}$ tumor or NIH3T3 supernatants were collected and treated with myeloid precursor cells for 5 days. SN, supernatants (A) Cell pretreated with tumor or NIH3T3 supernatants were labeled with antibody to CD80, CD86, Ia, and CD40, respectively, for phenotypic analysis by flow cytometry. Dotted lines represent isotype control. Number in histograms indicated geometric mean fluorescence intensity; (B) Mean fluorescence intensity of CD80, CD86, Ia, CD40, CD11c and CCR7. Results were the mean \pm SD of three independent experiments. ${ }^{*} p<0.05$; (C) NO expression and cytokine profile of cells from different pretreated groups for $24 \mathrm{~h}$. On day 6 , cells of different groups were collected and washed with PBS 3 times and placed in wells for another $24 \mathrm{~h}$. Then IL-12, IL-6, TNF, IL-10, TGF- $\beta$ were assayed by ELISA and NO were assayed by Griess. Results were the mean \pm SD of triplicate wells. ${ }^{*} p<0.05$; NS, no significance; (D) $\mathrm{CD}^{+} \mathrm{T}$ cells from DO11.10 OVA323-339 specific mice were co-cultured with cells from all groups, 5 days later, the total number of viable $\mathrm{CD}^{+}{ }^{\mathrm{T}}$ cells $\left(\mathrm{CD}^{+} 7 \mathrm{AAD}^{-}\right)$cells in each well was measured by flow cytometry. Results are the mean $\pm \mathrm{SD}$ of three independent analyses. $* p<0.05$.
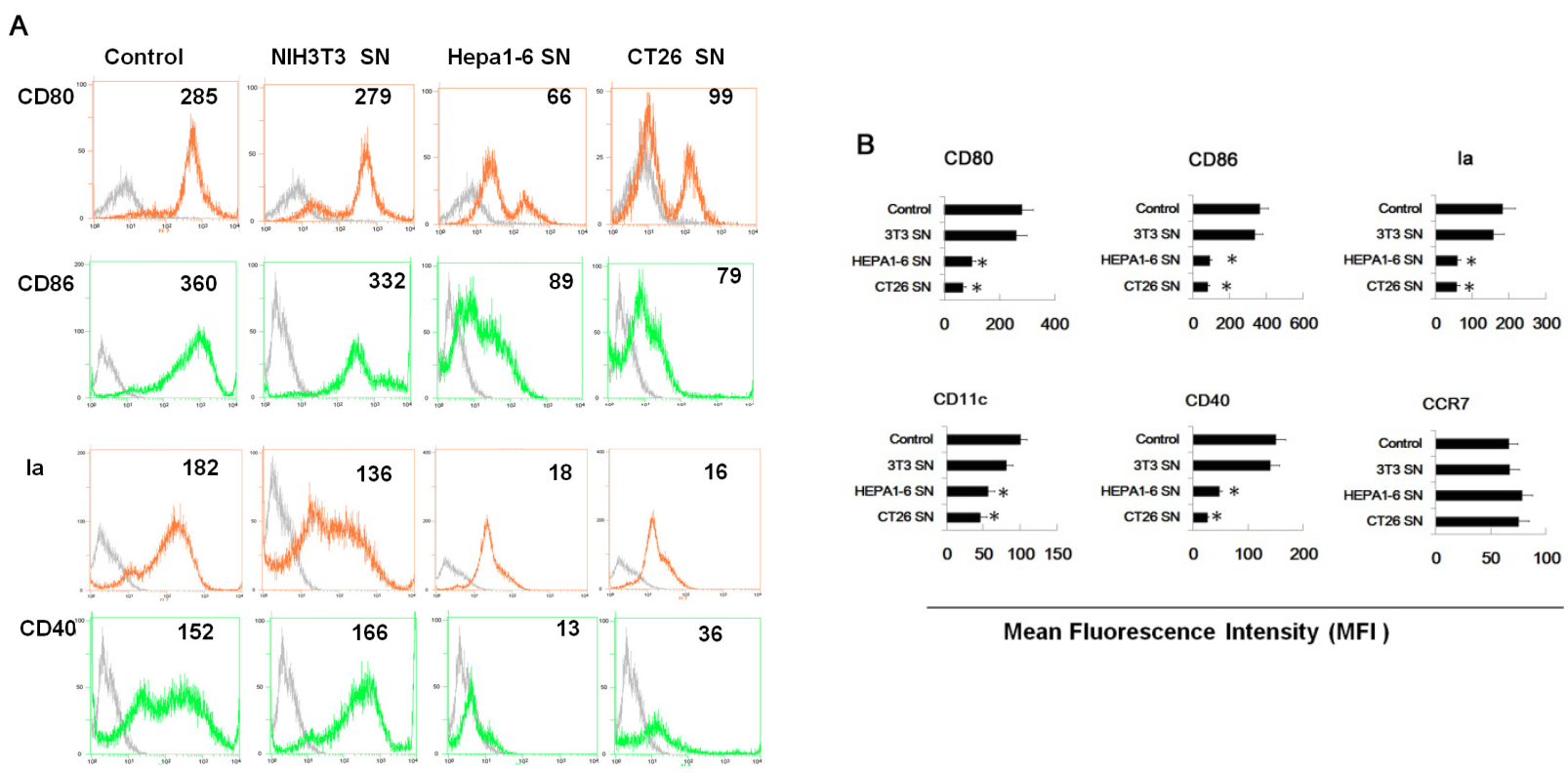
Figure 1. Cont.
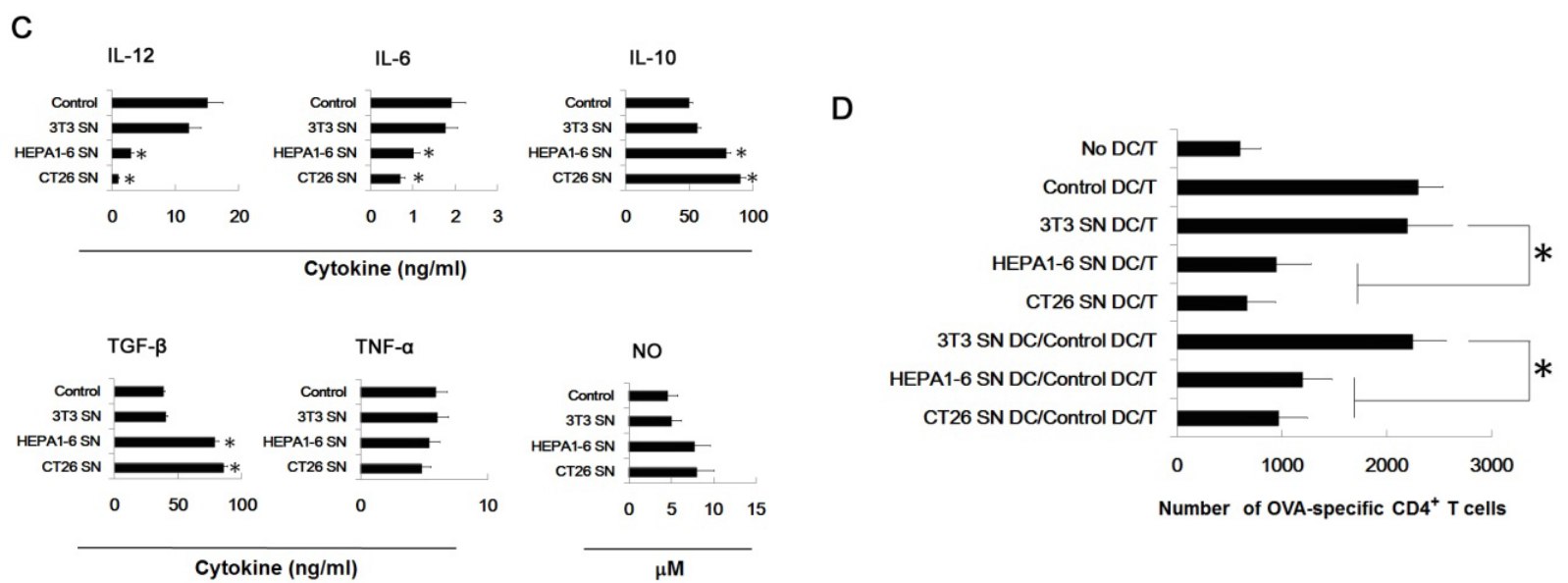

As shown in Figure 1A, after co-culture with supernatants of fibroblast (NIH3T3) or tumor cells (Hepa1-6, CT26), these cells showed a very different phenotype. Cells co-cultured with tumor supernatant showed a lower expression of CD80, CD86, Ia, CD11c and CD40, and the difference of CCR7 among these three groups was not significant (CD11c is generally expressed by dendritic cells; Ia belongs to Class II MHC antigen; CD40, CD80, CD86 are co-stimulatory molecules of dendritic cells; CCR7 is a chemotactic receptor that induces the dendritic cell to the lymphatic system.). Tumor supernatant treated cells secreted lower levels of IL-12 and IL-6, higher levels of IL-10, TGF- $\beta$ and NO.

Wen next tested whether these cells exerted immunoregulatory function by stimulating antigen-specific $\mathrm{T}$ cells responses. We found that tumor supernatant treated cells showed reduced ability to stimulate proliferation of OVA-specific $\mathrm{CD}^{+} \mathrm{T}$ cells. Significantly, we added cells co-cultured with supernatants of tumor cells into the $\mathrm{mDCs} / \mathrm{CD} 4^{+} \mathrm{T}$ co-culture system; we found the $\mathrm{T}$ cells proliferation in vitro was partly suppressed.

\subsection{Supernatants of Tumor Cells Inhibit the DC Differentiation from Myeloid Precursor Cells, and} Promote MDSC Accumulation

The cells treated with supernatants of tumor cells showed low expression of co-stimulatory molecules and a cytokine profile of low expression of IL-12, IL-6 and high expression IL-10 and TGF- $\beta$. In mice, phenotype of MDSC is $\mathrm{Gr}^{+} \mathrm{CD} 11 \mathrm{~b}^{+}[11]$, so we analyzed these population by double staining, and found more double-positive cells $\left(\mathrm{Gr} 1^{+} \mathrm{CD} 11 \mathrm{~b}^{+}\right.$cells) existed in Hepa1-6 cells group (19.3\%) and CT26 cells group (34.5\%) (Figure 2A). To exclude the possibility that this is the artificial phenomenon observed in vitro, we tried to confirm whether $\mathrm{Gr} 1^{+} \mathrm{CD} 11 \mathrm{~b}^{+}$cells exist in spleen of tumor-bearing mice. As shown in Figure $2 \mathrm{~B}, \mathrm{Gr} 1^{+} \mathrm{CD} 11 \mathrm{~b}^{+}$cells did exist in the spleen and constituted $11.3 \%$ of total karyocyte in spleen; in addition the percent of DC (CD11 ${ }^{+}$cells) in spleen of tumor-bearing mice is lower than negative control mice. 
Figure 2. Supernatants of tumor cells inhibit DC and promoted MDSC accumulation. (A) Myeloid precursor cells co-cultured with supernatants method was indicated as previously. After co-culture, treated cells were washed with PBS 3 times, and doubled-labeled with $\mathrm{Ab}$ to $\mathrm{Gr} 1$ and $\mathrm{CD} 11 \mathrm{~b}$, for phenotypic analysis by flow cytometry; (B) The percent of MDSC and DC in the spleen of tumor-bearing mice were assayed by FACS. Spleens were isolated from tumor-bearing mice, after depletion of red blood cells, were labeled $\mathrm{Ab}$ to $\mathrm{Gr} 1$ and $\mathrm{CD} 11 \mathrm{~b}$ or labeled $\mathrm{Ab}$ to CD11c. Percent of MDSC $\left(\mathrm{Gr}^{+} \mathrm{CD} 11 \mathrm{~b}^{+}\right)$and percent of DC(CD11c $\left.{ }^{+}\right)$were calculated by FACS. $* p<0.05$.

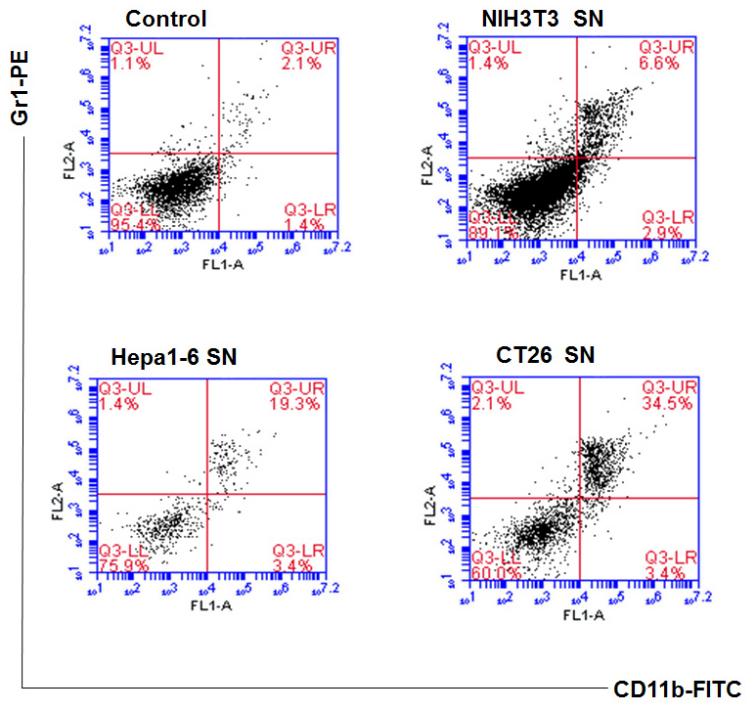

(A)

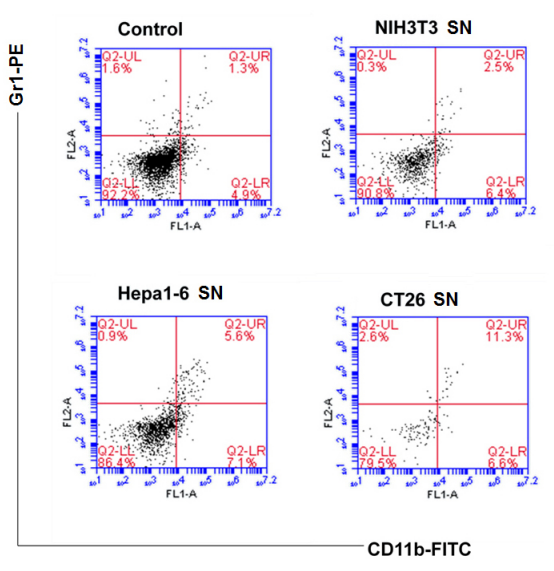

(B)

Figure 3. Twist regulated the effect of tumor cells of inducing myeloid precursor cells into MDSC. (A) Firstly, the relative mRNA expression of Twist of CT26, Hepa1-6 and NIH3T3 cells were assayed by real time PCR. Histograms represent the relative mRNA expression. Results were the mean $\pm \mathrm{SD}$ of three independent assays. ${ }^{*} p<0.05$; (B) CT26 cells were transfected with Twist siRNA (Twist S1, Twist S2, Twist S3 and Mock siRNA) as method indicated. Relative Twist mRNA expression was assayed by real time PCR. Results were the mean $\pm \mathrm{SD}$ of three independent assays. ${ }^{*} p<0.05$; (C) Hepa1-6 cells were transfected with Twist siRNA (Twist S1, Twist S2, Twist S3 and Mock siRNA) as method indicated. Relative Twist mRNA expression was assayed by real time PCR. Results were the mean $\pm \mathrm{SD}$ of three independent assays. $* p<0.05$; (D) NIH3T3 were transfected with Twist overexpression plasmid (pBABE-puro-mTwist), negative control plasmid (pBABE-puro) and blank control (No Plasmid). The relative Twist mRNA expression was then assayed by real time PCR. Results were the mean \pm SD of three independent assays. * $p<0.05$; (E) The supernatants of siRNA transfected CT26 cells were collected and co-cultured with myeloid precursor cells, and then these cells were purified for MDSC phenotype identification. The percent of $\mathrm{Gr}^{+} \mathrm{CD}^{+} 1 \mathrm{~b}^{+}$were $16.4 \%$ (Twist siRNA) and $34.0 \%$ (control siRNA) respectively; (F) After co-cultured with supernatants, these cells were labeled with $\mathrm{Ab}$ to $\mathrm{CD} 80$ and $\mathrm{CD} 86$, and assayed by FACS respectively. Results were the mean $\pm \mathrm{SD}$ of three independent assays. ${ }^{*} p<0.05$; $(\mathbf{G}) \mathrm{CD}^{+} \mathrm{T}$ cells from DO11.10 
OVA323-339-specific (TCR-transgenic $\times$ C57BL/6) F1 hybrid mice were co-cultured with pretreated myeloid precursor cells, 5 days later, the total number of viable $\mathrm{CD}^{+} \mathrm{T}$ cells $\left(\mathrm{CD} 4^{+}\right.$ 7AAD ${ }^{-}$) cells in each well was measured by flow cytometry. Results are the mean \pm SD of three independent analysis. ${ }^{*} p<0.05 \mathrm{SN}$, supernatants; (H) Twist expression of NIH3T3 cells was upregulated by transfection pBABE-puro-mTwist, then the supernatants of transfected NIH3T3 were collected for co-culture of myeloid precursor cells, and these cells were washed with PBS 3 times and co-cultured with $\mathrm{CD}^{+} \mathrm{T}$ cells as previous method indicate. Results are the mean $\pm \mathrm{SD}$ of three independent analyses. ${ }^{*} p<0.05 \mathrm{SN}$, supernatants; (I) After co-cultured with supernatants of pBABE-puro-mTwist transfected NIH3T3, the myeloid precursor cells were labeled with Ab to Gr1 and CD11b, and percent of MDSC $\left(\mathrm{Gr}^{+} \mathrm{CD}^{+} 1 \mathrm{~b}^{+}\right)$were counted by FACS. The percent of MDSC were $21.8 \%$ (pBABE-puro-mTwist) and 4.6\% (negative control, pBABE-puro) respectively.
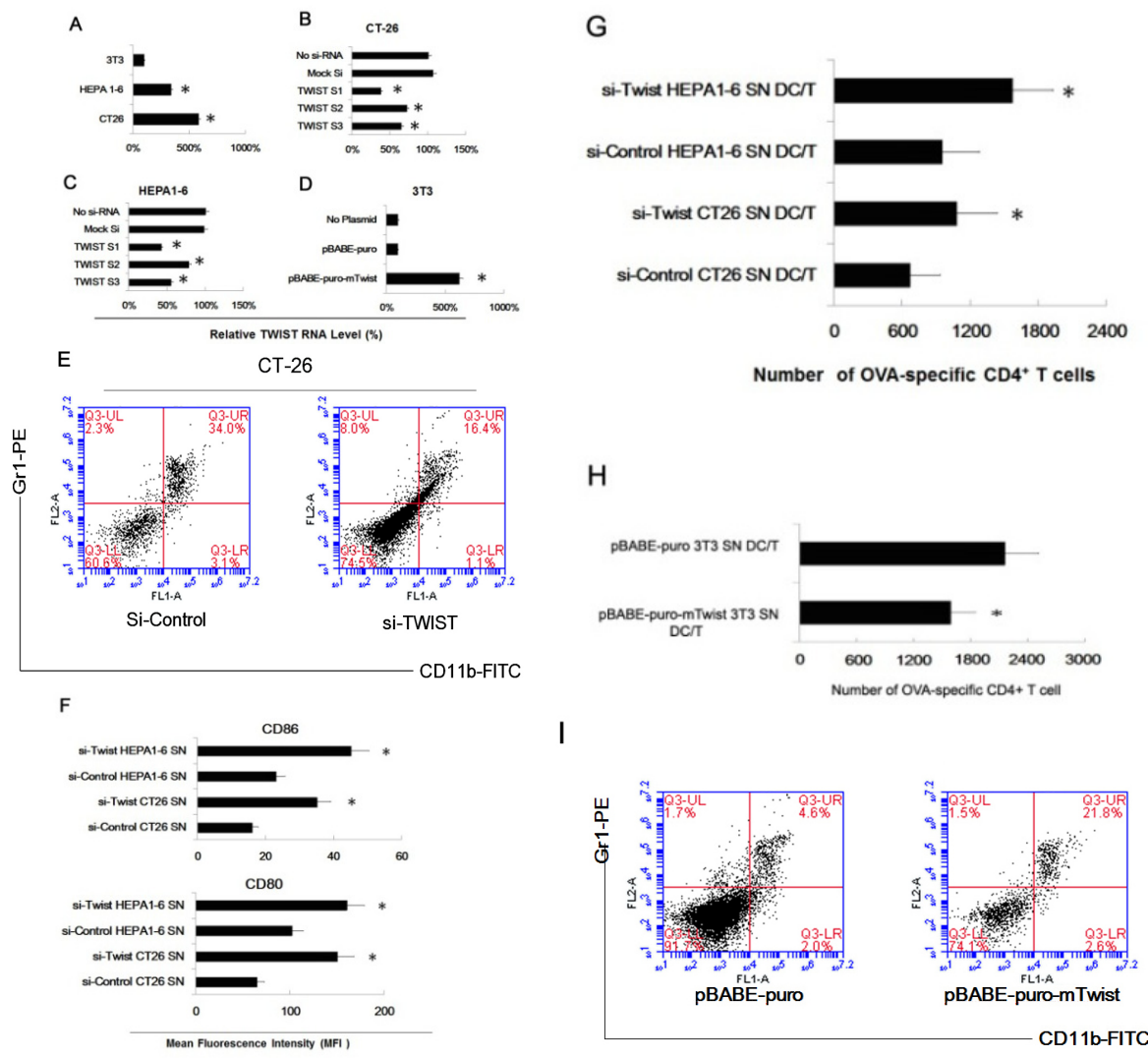

\subsection{Twist Regulated the Effect of Tumor Cells of Inducing Myeloid Precursor Cells into MDSC}

Twist, a master regulator of embryonic morphogenesis, plays an essential role in tumor metastasis. The suppression of Twist expression in highly metastatic mammary carcinoma cell specifically inhibits their ability to metastasize from the mammary gland to the lung [28]. So, we tested the Twist expression of the three cell lines, and found that the expression of Twist in Hepa1-6 and CT-26 cells is higher than in NIH3T3 cells (Figure 3A). Next, we downregulated Twist expression in two tumor cell lines by Twist-siRNA and upregulated the Twist expression by plasmid transfection (pBABE-puro-mTwist). As shown in Figure 3B,C, Twist expression in the two tumor cell line were downregulated by all three Twist siRNA, and Twist siRNA1 showed the most potent ability. After 
Twist overexpression plasmid (pBABE-puro-mTwist) transfection, the expression of Twist of NIH3T3 was upregulated to a very high level (Figure 3D). Next, we repeated our previous myeloid precursor cells and tumor supernatants co-culture experiments by using the three pretreated cell lines. Similarly, we purified and analyzed tumor supernatants treated myeloid precursor cells, and found a similar phenomenon in both Hepa1-6 and CT-26 supernatant pretreated group. We proved that Twist siRNA could decrease the percent of $\mathrm{Grl}^{+} \mathrm{CD} 11 \mathrm{~b}^{+}$cells in a population (Figure 3E). And unsurprisingly, CD86 and CD80 expression is higher in Twist-siRNA treated cells than in control (Figure 3F). Twist-siRNA partially restored the ability of the tumor supernatant pretreated cells to stimulate proliferation of OVA-specific $\mathrm{CD}^{+} \mathrm{T}$ cells (Figure 3G). Similarly, we upregulated Twist expression of NIH3T3 by transfection pBABE-puro-mTwist, and used supernatants of transfected NIH3T3 cells to co-culture with myeloid precursor cells. We found that the percent of $\mathrm{Gr}^{+} \mathrm{CD} 11 \mathrm{~b}^{+}$cells in population was increased (Figure $3 \mathrm{H}$ ) and these cells showed a decreased ability to stimulate proliferation of OVA-specific $\mathrm{CD}^{+} \mathrm{T}$ cells (Figure 3I).

\subsection{MiR-34a Regulated the Effect of Tumor Cells of Inducing Myeloid Precursor Cells into MDSC}

Gene encoding miRNAs in the miR-34 family are direct transcriptional targets of p53, whose induction by DNA damage and oncogenic stress depends on 553 both in vitro and in vivo. It has been proven the miR-34a is a tumor suppressor, and miR-34a could reduce cell proliferation and invasiveness [40]. Here, we found that the expression of miR-34a is lower in CT26 and Hepa1-6 cells than in NIH3T3 cells (Figure 4A). So, we upregulated the miR-34a expression by miR-34a specific mimics in tumor cell lines (CT-26 and Hepa1-6) and downregulated miR-34a expression in NIH3T3 cells by an miR-34a specific inhibitor (Figure 4B,C). Since the miR-34a expression of CT26 was changed more dramatically than Hepa1-6, we upregulated the miR-34a expression of CT26 cells and found higher expression of miR-34a led a lower percent of $\mathrm{Grl}^{+} \mathrm{CD} 11 \mathrm{~b}^{+}$cells $(22.9 \%)$ in the population as comparing with control (34.0\%) (Figure 4D). Then the $\mathrm{T}$ cell proliferation experiment indicated that higher expression of miR-34a in CT26 resulted in more proliferation of OVA-specific $\mathrm{CD}^{+} \mathrm{T}$ cells (Figure 4C) (Figure 4E), and lower expression of miR-34a in NIH3T3 resulted in less proliferation OVA-specific $\mathrm{CD}^{+} \mathrm{T}$ cells (Figure 4F).

\subsection{The Combined Effect of Twist and miR-34a on Inducing MDSC}

Having shown that both Twist and miR-34a play important roles in the process of inducing marrow precursor cells into MDSC, we decided to investigate treatment with combined Twist knockout and miR-34a mimics. We analyzed the phenotype of the treated myeloid precursor cells and found that combined treatment resulted in a lower percent of $\mathrm{Gr}^{+}{ }^{+} \mathrm{CD} 11 \mathrm{~b}^{+}$cells $(6.1 \%$ versus $23.9 \%)$ (Figure $\left.5 \mathrm{~A}\right)$. Next we found these pretreated cells showed the most potent ability of stimulating proliferation of OVA-specific $\mathrm{CD}^{+} \mathrm{T}$ cells (Figure 5B). And then we transfected CT26 cells with miR-34a mimics and Twist-siRNA, and inoculated these cells s.c. (subcutaneously) into C57BL/6 mice. Two weeks later, spleens of the tumor bearing mice were isolated for assaying the percent of MDSC or DC; a similar phenomenon was seen in vivo (6.2\% versus $11.6 \%)$ (Figure $5 \mathrm{C})$. Different combination of transfection pretreatment indicated that combination of miR-34a mimics and Twist siRNA showed the greatest effect (Figure 5D,E). 
Figure 4. The role of miR-34a in the process of inducing myeloid precursor cells into MDSC. The miR-34a expressions of CT26, Hepa1-6 and NIH3T3 cells were upregulated or downregulated by transfection of miR-34a mimics or specific inhibitors. Supernatants were collected separately following co-cultured experiments with myeloid precursor cells. These cells co-cultured with pretreated supernatants showed a lower percent MDSC phenotype and an increased capacity to stimulate the proliferation of $T$ cells. (A) The relative miR-34a expression of CT26, Hepa1-6 and NIH3T3 cells were assayed by real time PCR. Histograms represent the relative mRNA expression. Results were the mean \pm SD of three independent assays. ${ }^{*} p<0.05$; (B) After the transfection of miR-34a mimic, the expression of miR-34a of CD26 and Hepa1-6 cells were assayed. The relative expression is shown. Results were the mean $\pm \mathrm{SD}$ of three independent assays. $* p<0.05$; (C) After the transfection of the miR-34a specific inhibitor, the expression of miR-34a of NIH3T3 cells were assayed. Results were the mean \pm SD of three independent assays. ${ }^{*} p<0.05$; (D) miR-34a mimics were transfected into CT26 cell, and the supernatants of transfected CT26 cells were collected and co-cultured with myeloid precursor cells like before. As previously, the percent of MDSC were assayed by FACS: $34.0 \%$ (miR-NC mimic) versus $22.9 \%$ (miR-34a mimic). NS, negative control (E) $\mathrm{CD}^{+} \mathrm{T}$ cells from DO11.10 OVA323-339-specific (TCR-transgenic $\times$ C57BL/6) F1 hybrid mice were co-cultured with pretreated myeloid precursor cells (tumor cell supernatants pretreated), 5 days later, the total number of viable $\mathrm{CD}^{+}{ }^{+}$cells $\left(\mathrm{CD}^{+}{ }^{+} \mathrm{AAD}^{-}\right)$cells in each well was measured by flow cytometry. Results are the mean \pm SD of three independent analyses. $* p<0.05 \mathrm{SN}$, supernatants $(\mathbf{F}) \mathrm{CD}^{+} \mathrm{T}$ cells from DO11.10 OVA323-339-specific (TCR-transgenic $\times$ C57BL/6) F1 hybrid mice were co-cultured with pretreated myeloid precursor cells (NIH3T3 supernatants pretreated), 5 days later, the total number of viable $\mathrm{CD}^{+}{ }^{+}$cells $\left(\mathrm{CD}^{+} 7 \mathrm{AAD}^{-}\right)$cells in each well was measured by flow cytometry. Results are the mean $\pm \mathrm{SD}$ of three independent analyses. ${ }^{*} p<0.05 \mathrm{SN}$, supernatants.

A

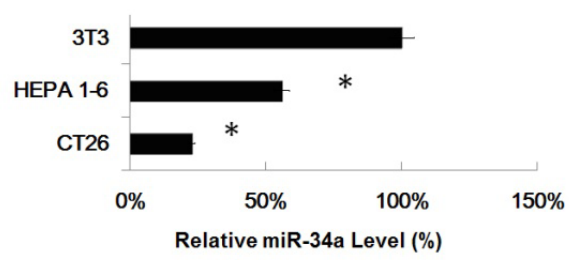

B

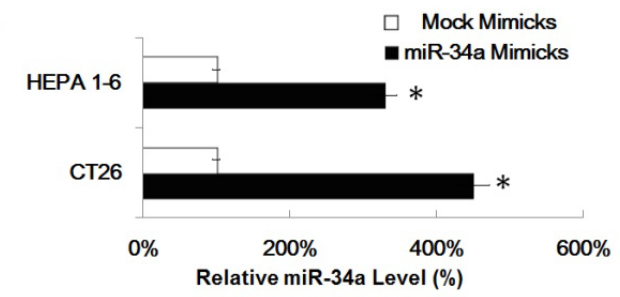

C

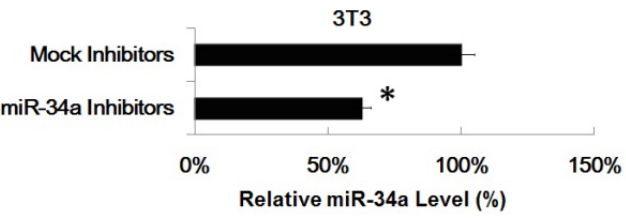

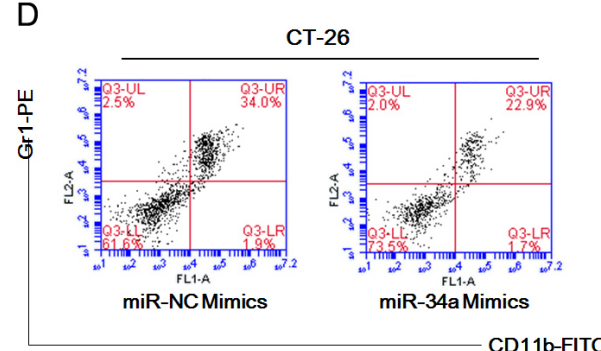

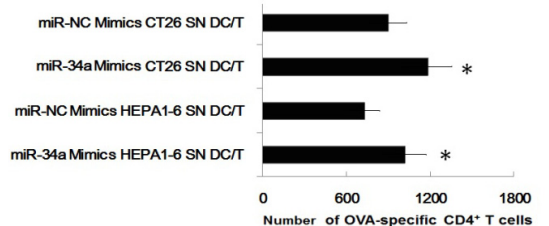

$\mathrm{F}$

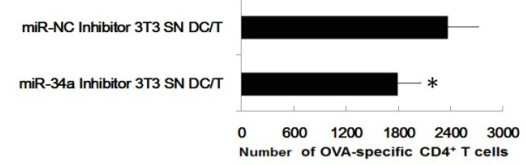


Figure 5. The combined effect of Twist and miR-34a in inducing MDSC. miRNA-34a mimics and Twist siRNA were combined to pretreated tumor cells. The supernatants of pretreated cells were collected and co-cultured with myeloid precursor cells; or the combined treated tumor cells were inoculated s.c. into C57BL/6 mice for the construction of tumor bearing mice model. After co-culture, these cell were purified to assess the percent of MDSC and the capacity to stimulate the proliferation of T cells. (A) Percent of $\operatorname{MDSC}\left(\mathrm{G} 1^{+} \mathrm{CD} 11 \mathrm{~b}^{+}\right)$in the pretreated cells population was assayed by FACS; (B) CD4 ${ }^{+} \mathrm{T}$ cells from DO11.10 OVA323-339-specific (TCR-transgenic $\times$ C57BL/6) F1 hybrid mice were co-cultured with four different pretreated myeloid precursor cells, 5 days later, the total number of viable $\mathrm{CD} 4^{+} \mathrm{T}$ cells $\left(\mathrm{CD}^{+}{ }^{+} \mathrm{AAD}^{-}\right)$cells in each well was measured by flow cytometry. Results are the mean $\pm \mathrm{SD}$ of three independent analyses. ${ }^{*} p<0.05 \mathrm{SN}$, supernatants; $(\mathbf{C})$ The spleens of tumor bearing mice were isolated for assaying the percent of MDSC $\left(\mathrm{Gr}^{+} \mathrm{CD} 11 \mathrm{~b}^{+}\right)$; (D) The percent of MDSC $\left(\mathrm{Gr} 1^{+} \mathrm{CD} 11 \mathrm{~b}^{+}\right)$in spleens of tumor bearing mice were assayed by FACS. There are four different pretreatment combinations. Results are the mean \pm SD of three independent analyses. ${ }^{*} p<0.05$; (E) The percent of DC $\left(\mathrm{CD} 11 \mathrm{c}^{+}\right)$in spleens of tumor bearing mice was assayed by FACS. Results are the mean \pm SD of three independent analyses. ${ }^{*} p<0.05$.

A

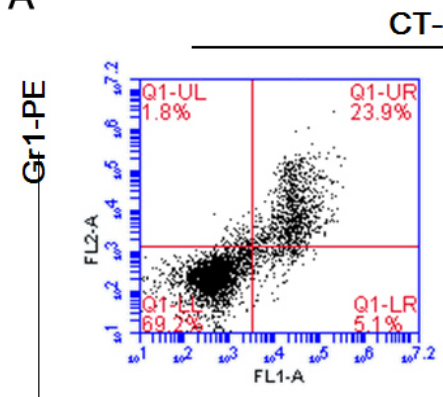

miR-NCMimics+MockSi

C

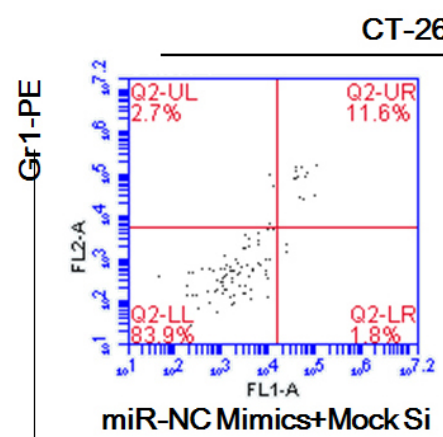

CT-26 In vitro

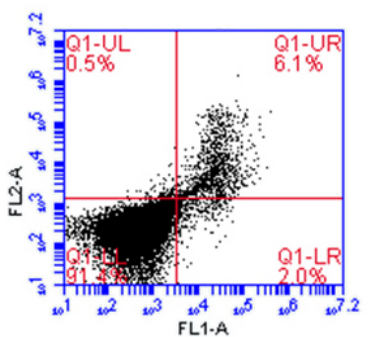

miR-34a Mimics+TWIST Si CD11b-FITC

In vivo

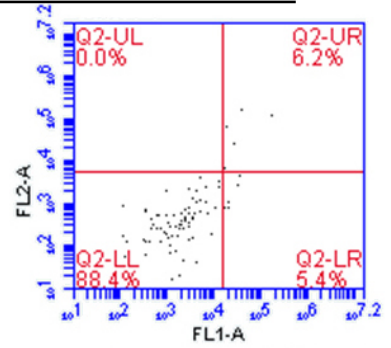

miR-34a Mimics+TWIST Si
B
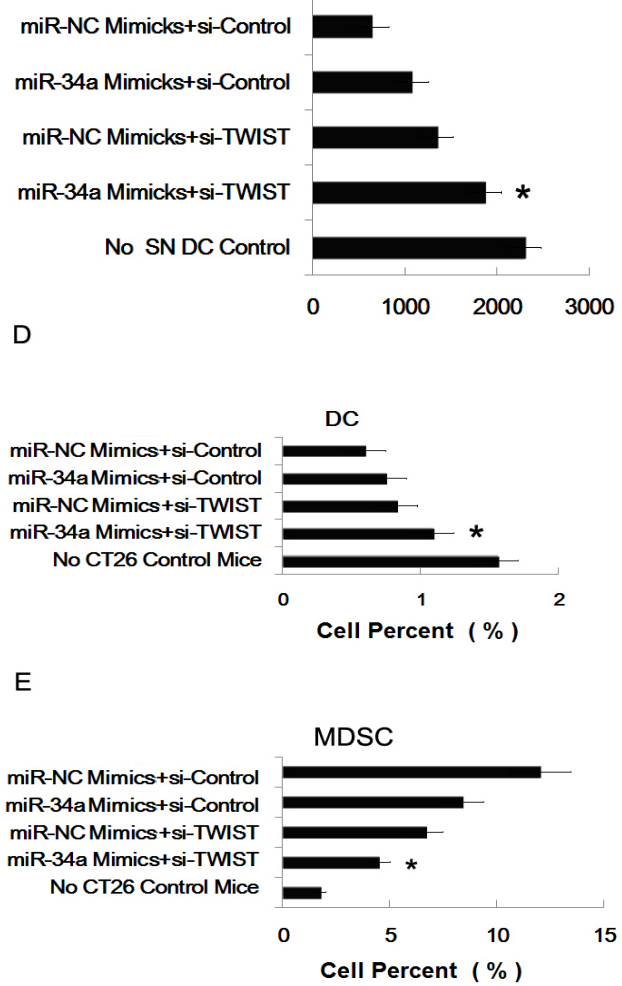

\subsection{Tumor-Derived IL-10 and TGF- $\beta$ Are Responsible for the Differentiation of MDSC}

To elucidate the mechanism involved in tumor supernatants inducing myeloid precursor cells into MDSC, we assayed cytokines in the supernatants of NIH3T3, Hepa1-6 and CT-26 cells, and found tumor cell lines secreted high level of IL-10 and TGF- $\beta$ than NIH3T3 (Figure 6A). We also proved that miR-34a mimics and Twist siRNA could suppress the secretion of IL-10 and TGF- $\beta$. It is noted 
that Twist siRNA could inhibit the secretion of both IL-10 and TGF- $\beta$, and miR-34a could only suppress the secretion of TGF- $\beta$ (Figure 6B). At last, we found that recombinant TGF- $\beta$ and IL-10 showed a similar effect comparing with tumor supernatants, and neutralizing Abs to TGF- $\beta$ and IL-10 could reduce the effect of tumor supernatants. As Figure 6C,D indicated, recombinant TGF- $\beta$ and IL-10 could lead to the accumulation of MDSC, and reduce the capacity of co-cultured cells to stimulate proliferation of T cells. Unsurprising, neutralizing Abs to TGF- $\beta$ and IL-10 showed a reverse effect.

Figure 6. Tumor supernatants induced myeloid precursor cells into MDSC, not DC via TGF- $\beta$ or IL-10. (A) The IL-10 and TGF- $\beta$ level in supernatant of the three cell lines were assayed by ELISA. Results are the mean $\pm \mathrm{SD}$ of three triplicate wells. ${ }^{*} p<0.05 \mathrm{SN}$, supernatants; (B) The IL-10 and TGF- $\beta$ level in supernatant of the transfected cells were assayed by ELISA. After plasmid or siRNA transfection, cells were washed by PBS 3 time, and then $24 \mathrm{~h}$ supernatants were collected for ELISA assay. Results are the mean $\pm \mathrm{SD}$ of three triplicate wells. ${ }^{*} p<0.05 \mathrm{SN}$, supernatant; (C) $\mathrm{CD}^{+} \mathrm{T}$ cells from DO11.10 OVA323-339-specific (TCR-transgenic $\times$ C57BL/6) F1 hybrid mice were co-cultured with pretreated myeloid precursor cells, 5 days later, the total number of viable $\mathrm{CD}^{+} \mathrm{T}^{-}$cells $\left(\mathrm{CD}^{+}{ }^{+} 7 \mathrm{AAD}^{-}\right)$in each well was measured by flow cytometry. Results are the mean $\pm \mathrm{SD}$ of three independent analyses. ${ }^{*} p<0.05 \mathrm{SN}$, supernatants; (D) Percent of $\operatorname{MDSC}\left(\mathrm{Gr}^{+} \mathrm{CD} 11 \mathrm{~b}^{+}\right)$in the pretreated cells population were analyzed by FACS.

A
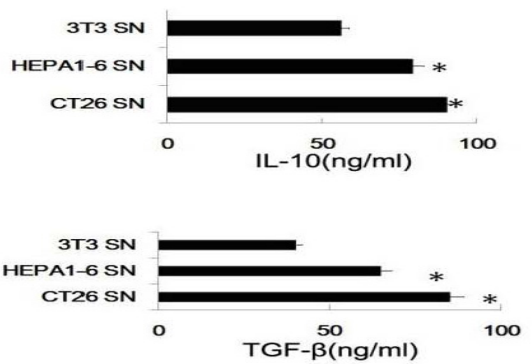

B

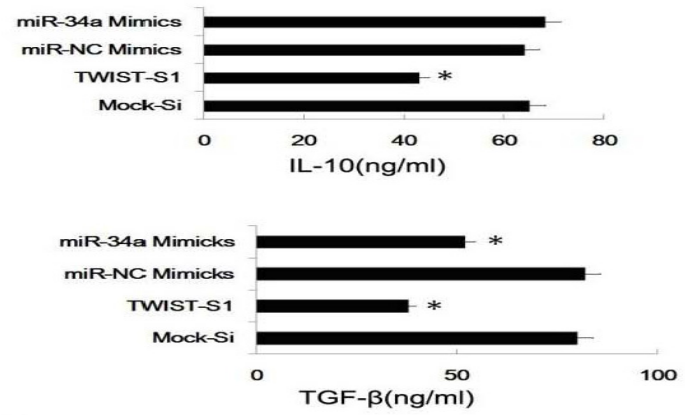

C

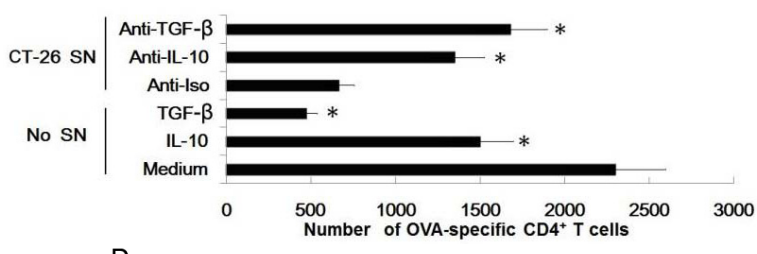

$\mathrm{D}$

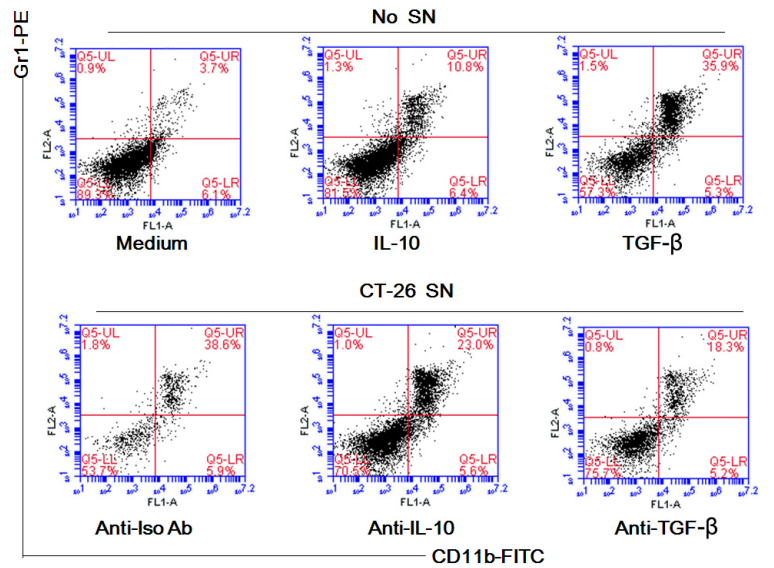

\subsection{Discussion}

Five possibilities for tumor-associated DC may be involved in tumor escape from immunological attack have been reported. Firstly, the capability of phagocytosis and Ag processing of DC may be inhibited by tumors. Secondly tumors can inhibit maturation of tumor-infiltrating imDC, which in turn may induce $\mathrm{T}$ cell tolerance/dysfunction. Thirdly, tumors and/or the tumor microenvironment can 
secrete some chemokines such as MIP-3 $\alpha$, which may selectively chemoattract imDCs to tumor tissue, and may inhibit mature DCs into the tumor tissue. Fourth, the ability of DC migrating out of the tumor and into lymph nodes may be impaired in the tumor microenvironment [2,47-51]. Fifthly, tumors can educate DCs to differentiate into a regulatory DC subset, which contributes to the constitution of the immunosuppressive tumor microenvironment and promotes tumor immune escape [8].

In our research, we proved that tumor supernatants could disturb the development of DC, and induce myeloid precursor cells into $\mathrm{CD}_{1} 1 \mathrm{~b}^{+} \mathrm{Gr} 1^{+}$cells with immune suppressive function. We considered that these cells may have a possibility to be MDSC. It has been shown that regulatory DC could be induced by tumors via TGF- $\beta$ and $\mathrm{PGE}_{2}$ [8]. It is noteworthy that in this research, our MDSC were induced from myeloid precursor cells and regulatory DC were derived from immature dendritic cells.

We found downregulation of Twist and upregulation of miR-34a in tumor cell lines could reduce the ability of tumor supernatants to induce myeloid precursor into MDSC. TGF- $\beta$ and IL-10 may be involved in the process.

Tumor cells secreted many immune suppressing cytokines such as TGF- $\beta$, VEGF, IL-10 and PGE 2 . It was shown that tumors can educate DCs to differentiate into regulatory DC subsets with immunosuppressive function via TGF- $\beta$, and $\mathrm{PGE}_{2}$. In our data, myeloid precursor cells can be induced into MDSC, not DC via TGF- $\beta$ and IL-10. Previous data indicated that MDSC was induced by activation via the IL-1 $\beta /$ IL-6 pathway [8], and we imagine that the mechanism involved in our research were different from this. So, it appears that immunosuppressive cytokines play multiple roles in DC development and differentiation.

Twist plays varied roles in cancer initiation, progression and metastasis. More specifically, Twist can: override oncogene-induced cell senescence and apoptosis [52-54]; increase cancer cell resistance to chemotherapy [55]; enhance cancer stem cell (CSC) populations [56-58]; and facilitate cancer cell invasion and metastasis [28,31,59-63]. In our research, we demonstrated that Twist plays a very indirect role; Twist siRNA could suppress the secretion of IL-10 and TGF- $\beta$, which played important roles in induction of MDSC. So, it seems that Twist not only changes the biological behavior of tumor cells, but also induces immunosuppressive cytokines, which help tumor cells escaping from immune attack However, the precise mechanism still needs further investigation. MicroRNA miR-34 was identified as a p53 target [40,42], and recently the miR-34 family was found to directly link p53 and Wnt, revealing the tight connection between loss of tumor suppressor function and activation of oncogenic signaling. As loss of wt-p53 or hyperactivation of Wnt is critical in maintaining cancer stem cell properties and in establishing the metastatic program, these observations indicate a mechanism of miR-mediated quasi-sufficiency which connects tumor suppressor and oncogenic signaling pathways, supporting a continuum model of human cancer. Interestingly, our data added the third role of miR-34a, we found miR-34 played an indirect role in inducing MDSC via TGF- $\beta$ and IL-10. Factors that induce MDSC expansion included cyclooxygenase-2 (COX2), prostaglandins [64-66], stem-cell factor (SCF) [64], macrophage colony-stimulating factor (M-CSF), IL-6 [67], GM-CSF and vascular endothelial growth factor (VEGF) [68]. Activation is necessary, and many factors are involved in activation, which include IFN- $\gamma$ [69,70], ligands for Toll-like receptors (TLRs), IL-13 [71], IL-4 and transforming growth factor- $\beta$ (TGF- $\beta$ ) [71]. Our data indicated that TGF- $\beta$ maybe also played an important role in MDSC differentiation. 
In conclusion, our data showed that tumor supernatants could induce myeloid precursor cells into MDSC, not DC. More importantly, we elucidated the role of Twist and miR-34a in the process. Our data provides two new molecular regulators which were involved in the accumulation of MDSC.

\section{Experimental Section}

\subsection{Mice and Treatment}

Male and female wild-type C57BL/6 mice, 5-6 weeks of age, were purchased from the Chinese Academy of Sciences (Shanghai, China). DO11.10 OVA323-339-specific TCR-transgenic mice with C57BL/6 background were obtained from The Jackson Laboratory. All mice were housed in a Specific Pathogen-Free (SPF) facility for all experiments. All animal experiments were undertaken in accordance with the National Institute of Health "Guide for the Care and Use of Laboratory Animals" (NIH Publication No. 85-23, National Academy Press, Washington DC, revised 1996), with the approval of the Laboratory Animal Center of the Second Military Medical University, Shanghai. All efforts were made to minimize the number of animals used as well as any suffering. The CT-26 colon cancer cell line, the Hepa1-6 hepatoma cell line, and the NIH3T3 fibroblast lines were all purchased from the American Type Culture Collection and maintained in RPMI 1640 complete medium (PAA Laboratories, GmbH, Pasching, Austria) supplemented with 10\% FCS (PAA Laboratories, $\mathrm{GmbH}$, Pasching, Austria).

\subsection{Reagents}

Recombinant mouse GM-CSF, IL-4, TGF- $\beta$, IL-10, neutralizing Abs to TGF- $\beta$ and IL-10 and ELISA kit for murine IL-12, IL-6, TNF- $\alpha$, IL-10, TGF- $\beta$ were purchased from R \& D Systems. Fluorescein-conjugated mAb to CD4, CD11b, CD80, CD86, Ia, CD40, CD11c, CCR7, Gr1, and isotype control were purchased from Santa Cruz Biotechnology. Fluorescein-conjugated mAbs to Gr1 were obtained from eBioscience. 7-Amnioactinomycin D (7-AAD), LPS were from Sigma-Aldrich (Sigma-Aldrich, St. Louis, MO, USA). miRNA miR-34a mimics, antagonists, and negative control miRNA mimic (NC mimic) were obtained from Dharmacon (Dharmacon, Chicago, IL, USA) [72].

\subsection{Preparation of Tumor Supernatants Treated Myeloid Precursor Cells}

Myeloid precursor cells were obtained from mice as described previously $[8,9,45,46]$. NIH3T3, Hepa1-6, and CT26 cells or these transfected cells were cultured in six-well plates $\left(1 \times 10^{6}\right.$ cells/well $)$, $12 \mathrm{~h}$ later they were washed with PBS 3 times. Fresh culture medium was then added to the wells. Twenty four hours later, supernatants were collected and co-cultured with myeloid precursor cells separately for 4 days. On day 6, cells in all groups were washed by PBS 3 times for further experiments.

\subsection{Flow Cytometry}

The phenotype of the cells and $\mathrm{T}$ cell response were analyzed by LSRII flow cytometry (BD Biosciences, Becton Dickinson, Franklin Lakes, NJ, USA) as described previously $[8,44,45]$. 


\subsection{Tumor Model, Preparation of DC and Spleen Cells}

The tumor model was constructed as previously indicated [8]. Tumor cells $\left(1 \times 10^{6} / 500 \mathrm{~mL}\right)$ were inoculated into C57BL/6 mice s.c.; 2 weeks later, these mice were euthanized for isolation of spleen. After depletion of red blood cells, spleen cells were doubled-labeled with Ab to Gr1 and Ab to CD11b for cytometry analysis. Bone marrow mononuclear cells were prepared from C57BL/6 mouse (5-6 weeks old) femur bone marrow suspensions by depletion of red cells and then were cultured at a density $2 \times 10^{6}$ cells $/ \mathrm{mL}$ in 6-well plates in RPMI 1640 medium supplemented with $10 \%$ FCS, $10 \mathrm{ng} / \mathrm{mL}$ of recombinant mouse granulocyte-monocyte colony-stimulating factor and $1 \mathrm{ng} / \mathrm{mL}$ of recombinant mouse IL-4. Nonadherent cells were gently washed out on day 4 of culture. At day 5 , the dendritic proliferating clusters were collected.

\subsection{Assay for Cytokines and NO}

Tumor cells or NIH3T3 cells were seeded into six-well plates at a density of $1.0 \times 10^{6} / \mathrm{ml} /$ well. After cells were adhered on plates, they were washed with PBS 3 times. The fresh medium was then added to the wells, and $24 \mathrm{~h}$ later, the cytokines were assayed with ELISA kits. NO production was assayed by measurement of the nitrite concentration with the Griess assay.

\subsection{Assays for Ag-Specific CD4 $4^{+}$Tell Response}

As mDC could effectively prime proliferation of OVA-specific CD4 ${ }^{+} \mathrm{T}$ cells [8], so Ag-specific $\mathrm{CD}^{+} \mathrm{T}$ cell response were performed to test the function of dendritic cells. For assay of Ag-specific $\mathrm{CD}^{+} \mathrm{T}$ cell proliferation splenic $\mathrm{CD}^{+} \mathrm{T}$ cells from DO11.10 OVA323-339-specific TCR-transgenic mice were positively selected with anti-CD4-coated microbeads (Miltenyi Biotec, Miltenyi Biotec, Bergisch Gladbach, GmbH, Germany) by MACS and the co-cultured with DCs treated as indicated in the presence of OVA323-339 peptide at a ratio of 1:10 (DC:T) in round-bottom 96-well plates $\left(1 \times 10^{5}\right.$ cells $/ 200 \mu /$ well $)$ for 5 days. Proliferation of $\mathrm{T}$ cells was analyzed by double staining with anti-CD4 ${ }^{+}$and $7-\mathrm{AAD}^{-}$cells were counted by FACS.

\subsection{Assay for Percent of MDSC and DC In Vivo}

The tumor bearing mice models were constructed by s.c. injection tumor cells $\left(1 \times 10^{6} / 500 \mathrm{~mL}\right)$ After 2 weeks, the spleens were isolated, and splenic single suspension cells were prepared, then they were stained with $\mathrm{Ab}-\mathrm{CD} 11 \mathrm{c}^{+}$conjugated FITC, Ab-CD11 $\mathrm{b}^{+}$conjugated $\mathrm{PE}$ or $\mathrm{Ab}-\mathrm{Gr} 1^{+}$conjugated FITC as standard protocol indicated.

\subsection{Real-Time RT-PCR}

The method of PCR was described by Yang et al. [28]. Mouse Twist RT-PCR forward primer is CGGGTCATGGCTAACGTG, and its RT-PCR reverse primer is CAGCTTGCCATCTTGGAGTC. miRNA-34a TaqMan assays were used to quantify levels of mature miRNA as described previously [73]. The primers of miR-34a were previously shown [40]. 


\subsection{Twist Plasmids and siRNA Transfection}

The method of transfection of Twist was described by Yang et al. [28]. The mouse Twist cDNA was achieved from Dr. Fabienne Perrin-Schmitt at Universite Louis Pasteur and subcloned into pBABE-puro vector (pBABE-puro-mTwist). pBABE-puro vector without mTwist subcloned as control.

Three siRNA-coding oligos against mouse Twist were designed and verified to be specific to Twist by Blast search against the mouse genome. Twist-siRNA1-targetting sequence is AAGCTGAGCA AGATTCAGACC; Twist-siRNA2-targetting sequence is AGCGGGTCATGGCTAACGTGC; Twist-siRNA2-targetting sequence is AGGTACATCGACTTCCTGTAC. We found Twist-siRNA1 showed the most potent effect, so we used Twist-siRNA1 in following experiments.

\subsection{Transfection of miR-34 Mimics and Combined Transfection}

Tumor cells were transfected $24 \mathrm{~h}$ after being seeded in 6-well plates. miRNA mimics (100 pmol) in $200 \mu \mathrm{L}$ of serum-free, antibiotic-free, medium were mixed with $5 \mu \mathrm{L}$ of Lipofectamine 2000 transfection reagent (Invitrogen, Carlsbad, CA, USA) dissolved in $200 \mu \mathrm{L}$ of the same medium and allowed to stand at room temperature for $20 \mathrm{~min}$. The resulting $400 \mu \mathrm{L}$ transfection solutions were then added to each well containing $1.6 \mathrm{~mL}$ of medium. Six hours later, the cultures were replaced with $2 \mathrm{~mL}$ fresh medium supplemented with 10\% FBS and antibiotics [74]. The combined transfection of Twist plasmid and miR-34a mimics required two steps; firstly, cells were transfected Twist plasmid as before, then $6 \mathrm{~h}$ later, miR-34a mimics were transfected as the previous method indicated.

\subsection{Statistical Analysis}

Comparisons between experimental groups and relevant controls were performed by Student's $t$ test or ANOVA. All the statistical analyses were performed with SPSS 16.0 (SPSS, Chicago, IL, USA, 2008) and $p<0.05$ was considered statistically significant.

\section{Conclusions}

In summary, we confirmed that tumor supernatants could disturb the development of DC, and induce myeloid precursor cells into $\mathrm{CD} 1 \mathrm{~b}^{+} \mathrm{Grl}^{+}$cells with immune suppressive function. We guessed that these cells may be MDSC. Interestingly, we found downregulation of Twist and upregulation of miR-34a in tumor cell lines could reduce the ability of tumor supernatants to induce myeloid precursor into MDSC. TGF- $\beta$ and IL-10 may be involved in the process.

\section{Acknowledgments}

Special thanks to Weimin Sun from department of immunology of our university for discussion.

\section{Conflicts of Interest}

The authors declare no conflict of interest. 


\section{References}

1. Kim, R.; Emi, M.; Tanabe, K.; Arihiro, K. Tumor-driven evolution of immunosuppressive networks during malignant progression. Cancer Res. 2006, 66, 5527-5536.

2. Rabinovich, G.A.; Gabrilovich, D.; Sotomayor, E.M. Immunosuppressive strategies that are mediated by tumor cells. Annu. Rev. Immunol. 2007, 25, 267-296.

3. Zou, W. Immunosuppressive networks in the tumour environment and their therapeutic relevance. Nat. Rev. Cancer 2005, 5, 263-274.

4. Wang, Y.; Ma, Y.; Fang, Y.; Wu, S.; Liu, L.; Fu, D.; Shen, X. Regulatory T cell: A protection for tumour cells. J. Cell Mol. Med. 2012, 16, 425-436.

5. Shurin, M.R.; Shurin, G.V.; Lokshin, A.; Yurkovetsky, Z.R.; Gutkin, D.W.; Chatta, G.; Zhong, H.; Han, B.; Ferris, R.L. Intratumoral cytokines/chemokines/growth factors and tumor infiltrating dendritic cells: Friends or enemies? Cancer Metastasis Rev. 2006, 25, 333-356.

6. Kusmartsev, S.; Gabrilovich, D.I. Effect of tumor-derived cytokines and growth factors on differentiation and immune suppressive features of myeloid cells in cancer. Cancer Metastasis Rev. 2006, 25, 323-331.

7. Lin, W.W.; Karin, M. A cytokine-mediated link between innate immunity, inflammation, and cancer. J. Clin. Invest. 2007, 117, 1175-1183.

8. Liu, Q.; Zhang, C.; Sun, A.; Zheng, Y.; Wang, L.; Cao, X. Tumor-educated CD11bhighIalow regulatory dendritic cells suppress $\mathrm{T}$ cell response through arginase I. J. Immunol. 2009, 182, 6207-6216.

9. Liu, C.; Zhang, C.; Lu, H.; Cai, J.; Wang, Z.; Chen, J.; Liu, F.; Wu, Z.; Liu, X.; Sun, W. Poly(I:C) induce bone marrow precursor cells into myeloid-derived suppressor cells. Mol. Cell. Biochem. 2011, 358, 317-323.

10. Greifenberg, V.; Ribechini, E.; Rossner, S.; Lutz, M.B. Myeloid-derived suppressor cell activation by combined LPS and IFN-gamma treatment impairs DC development. Eur. J. Immunol. 2009, 39, 2865-2876.

11. Gabrilovich, D.I.; Nagaraj, S. Myeloid-derived suppressor cells as regulators of the immune system. Nat. Rev. Immunol. 2009, 9, 162-174.

12. Bronte, V.; Zanovello, P. Regulation of immune responses by L-arginine metabolism. Nat. Rev. Immunol. 2005, 5, 641-654.

13. Rodriguez, P.C.; Ochoa, A.C. Arginine regulation by myeloid derived suppressor cells and tolerance in cancer: Mechanisms and therapeutic perspectives. Immunol. Rev. 2008, 222, 180-191.

14. Youn, J.I.; Nagaraj, S.; Collazo, M.; Gabrilovich, D.I. Subsets of myeloid-derived suppressor cells in tumor-bearing mice. J. Immunol. 2008, 181, 5791-5802.

15. Kusmartsev, S.; Nefedova, Y.; Yoder, D.; Gabrilovich, D.I. Antigen-specific inhibition of $\mathrm{CD}^{+} \mathrm{T}$ cell response by immature myeloid cells in cancer is mediated by reactive oxygen species. J. Immunol. 2004, 172, 989-999.

16. Schmielau, J.; Finn, O.J. Activated granulocytes and granulocyte-derived hydrogen peroxide are the underlying mechanism of suppression of T-cell function in advanced cancer patients. Cancer Res. 2001, 61, 4756-4760. 
17. Kusmartsev, S.; Nagaraj, S.; Gabrilovich, D.I. Tumor-associated $\mathrm{CD} 8^{+} \mathrm{T}$ cell tolerance induced by bone marrow-derived immature myeloid cells. J. Immunol. 2005, 175, 4583-4592.

18. Szuster-Ciesielska, A.; Hryciuk-Umer, E.; Stepulak, A.; Kupisz, K.; Kandefer-Szerszen, M. Reactive oxygen species production by blood neutrophils of patients with laryngeal carcinoma and antioxidative enzyme activity in their blood. Acta Oncol. 2004, 43, 252-258.

19. Waris, G.; Ahsan, H. Reactive oxygen species: Role in the development of cancer and various chronic conditions. J. Carcinog. 2006, 5, 14.

20. Mantovani, G.; Maccio, A.; Madeddu, C.; Mura, L.; Gramignano, G.; Lusso, M.R.; Massa, E.; Mocci, M.; Serpe, R. Antioxidant agents are effective in inducing lymphocyte progression through cell cycle in advanced cancer patients: Assessment of the most important laboratory indexes of cachexia and oxidative stress. J. Mol. Med. 2003, 81, 664-673.

21. Agostinelli, E.; Seiler, N. Non-irradiation-derived reactive oxygen species (ROS) and cancer: Therapeutic implications. Amino Acids 2006, 31, 341-355.

22. Yang, R.; Cai, Z.; Zhang, Y.; Yutzy, W.H.T.; Roby, K.F.; Roden, R.B. CD80 in immune suppression by mouse ovarian carcinoma-associated $\mathrm{Gr}-1^{+} \mathrm{CD} 11 \mathrm{~b}^{+}$myeloid cells. Cancer Res. 2006, 66, 6807-6815.

23. Huang, B.; Pan, P.Y.; Li, Q.; Sato, A.I.; Levy, D.E.; Bromberg, J.; Divino, C.M.; Chen, S.H. $\mathrm{Gr}-1^{+} \mathrm{CD} 115^{+}$immature myeloid suppressor cells mediate the development of tumor-induced $\mathrm{T}$ regulatory cells and T-cell anergy in tumor-bearing host. Cancer Res. 2006, 66, 1123-1131.

24. Steinman, R.M. The dendritic cell system and its role in immunogenicity. Annu. Rev. Immunol. 1991, 9, 271-296.

25. Banchereau, J.; Steinman, R.M. Dendritic cells and the control of immunity. Nature 1998, 392, 245-252.

26. Steinman, R.M.; Banchereau, J. Taking dendritic cells into medicine. Nature 2007, 449, 419-426.

27. Palucka, K.; Banchereau, J. Cancer immunotherapy via dendritic cells. Nat. Rev. Cancer 2012, 12, 265-277.

28. Yang, J.; Mani, S.A.; Donaher, J.L.; Ramaswamy, S.; Itzykson, R.A.; Come, C.; Savagner, P.; Gitelman, I.; Richardson, A.; Weinberg, R.A. Twist, a master regulator of morphogenesis, plays an essential role in tumor metastasis. Cell 2004, 117, 927-939.

29. Lee, T.K.; Poon, R.T.; Yuen, A.P.; Ling, M.T.; Kwok, W.K.; Wang, X.H.; Wong, Y.C.; Guan, X.Y.; Man, K.; Chau, K.L.; et al. Twist overexpression correlates with hepatocellular carcinoma metastasis through induction of epithelial-mesenchymal transition. Clin. Cancer Res. 2006, 12, 5369-5376.

30. Yang, M.H.; Chen, C.L.; Chau, G.Y.; Chiou, S.H.; Su, C.W.; Chou, T.Y.; Peng, W.L.; Wu, J.C. Comprehensive analysis of the independent effect of twist and snail in promoting metastasis of hepatocellular carcinoma. Hepatology 2009, 50, 1464-1474.

31. Kwok, W.K.; Ling, M.T.; Lee, T.W.; Lau, T.C.; Zhou, C.; Zhang, X.; Chua, C.W.; Chan, K.W.; Chan, F.L.; Glackin, C.; et al. Up-regulation of TWIST in prostate cancer and its implication as a therapeutic target. Cancer Res. 2005, 65, 5153-5162.

32. Yuen, H.F.; Chua, C.W.; Chan, Y.P.; Wong, Y.C.; Wang, X.; Chan, K.W. Significance of TWIST and E-cadherin expression in the metastatic progression of prostatic cancer. Histopathology 2007, $50,648-658$. 
33. Yuen, H.F.; Chan, Y.P.; Wong, M.L.; Kwok, W.K.; Chan, K.K.; Lee, P.Y.; Srivastava, G.; Law, S.Y.; Wong, Y.C.; Wang, X.; et al. Upregulation of Twist in oesophageal squamous cell carcinoma is associated with neoplastic transformation and distant metastasis. J. Clin. Pathol. 2007, 60, 510-514.

34. Sasaki, K.; Natsugoe, S.; Ishigami, S.; Matsumoto, M.; Okumura, H.; Setoyama, T.; Uchikado, Y.; Kita, Y.; Tamotsu, K.; Sakamoto, A.; et al. Significance of Twist expression and its association with E-cadherin in esophageal squamous cell carcinoma. J. Exp. Clin. Cancer Res. 2009, 28, 158.

35. Zhang, Z.; Xie, D.; Li, X.; Wong, Y.C.; Xin, D.; Guan, X.Y.; Chua, C.W.; Leung, S.C.; Na, Y.; Wang, X. Significance of TWIST expression and its association with E-cadherin in bladder cancer. Hum. Pathol. 2007, 38, 598-606.

36. Wallerand, H.; Robert, G.; Pasticier, G.; Ravaud, A.; Ballanger, P.; Reiter, R.E.; Ferriere, J.M. The epithelial-mesenchymal transition-inducing factor TWIST is an attractive target in advanced and/or metastatic bladder and prostate cancers. Urol. Oncol. 2010, 28, 473-479.

37. Satoh, K.; Hamada, S.; Kimura, K.; Kanno, A.; Hirota, M.; Umino, J.; Fujibuchi, W.; Masamune, A.; Tanaka, N.; Miura, K.; et al. Up-regulation of MSX2 enhances the malignant phenotype and is associated with twist 1 expression in human pancreatic cancer cells. Am. J. Pathol. 2008, 172, 926-939.

38. Qin, Q.; Xu, Y.; He, T.; Qin, C.; Xu, J. Normal and disease-related biological functions of Twist1 and underlying molecular mechanisms. Cell Res. 2012, 22, 90-106.

39. Ambros, V. The functions of animal microRNAs. Nature 2004, 431, 350-355.

40. He, L.; He, X.; Lim, L.P.; de Stanchina, E.; Xuan, Z.; Liang, Y.; Xue, W.; Zender, L.; Magnus, J.; Ridzon, D.; et al. A microRNA component of the p53 tumour suppressor network. Nature 2007, 447, 1130-1134.

41. Chang, T.C.; Wentzel, E.A.; Kent, O.A.; Ramachandran, K.; Mullendore, M.; Lee, K.H.; Feldmann, G.; Yamakuchi, M.; Ferlito, M.; Lowenstein, C.J.; et al. Transactivation of miR-34a by p53 broadly influences gene expression and promotes apoptosis. Mol. Cell 2007, 26, 745-752.

42. Bommer, G.T.; Gerin, I.; Feng, Y.; Kaczorowski, A.J.; Kuick, R.; Love, R.E.; Zhai, Y.; Giordano, T.J.; Qin, Z.S.; Moore, B.B.; et al. p53-mediated activation of miRNA34 candidate tumor-suppressor genes. Curr. Biol. 2007, 17, 1298-1307.

43. He, X.; He, L.; Hannon, G.J. The guardian's little helper: MicroRNAs in the p53 tumor suppressor network. Cancer Res. 2007, 67, 11099-11101.

44. Zhang, M.; Tang, H.; Guo, Z.; An, H.; Zhu, X.; Song, W.; Guo, J.; Huang, X.; Chen, T.; Wang, J.; et al. Splenic stroma drives mature dendritic cells to differentiate into regulatory dendritic cells. Nat. Immunol. 2004, 5, 1124-1133.

45. Tang, H.; Guo, Z.; Zhang, M.; Wang, J.; Chen, G.; Cao, X. Endothelial stroma programs hematopoietic stem cells to differentiate into regulatory dendritic cells through IL-10. Blood 2006, $108,1189-1197$.

46. Xia, S.; Guo, Z.; Xu, X.; Yi, H.; Wang, Q.; Cao, X. Hepatic microenvironment programs hematopoietic progenitor differentiation into regulatory dendritic cells, maintaining liver tolerance. Blood 2008, 112, 3175-3185.

47. Ferrone, S.; Whiteside, T.L. Tumor microenvironment and immune escape. Surg. Oncol. Clin. N. Am. 2007, 16, 755-774. 
48. Fricke, I.; Gabrilovich, D.I. Dendritic cells and tumor microenvironment: A dangerous liaison. Immunol. Invest. 2006, 35, 459-483.

49. Drake, C.G.; Jaffee, E.; Pardoll, D.M. Mechanisms of immune evasion by tumors. Adv. Immunol. 2006, 90, 51-81.

50. Hurwitz, A.A.; Watkins, S.K. Immune suppression in the tumor microenvironment: A role for dendritic cell-mediated tolerization of T cells. Cancer Immunol. Immunother. 2012, 61, 289-293.

51. Dhodapkar, M.V.; Dhodapkar, K.M.; Palucka, A.K. Interactions of tumor cells with dendritic cells: Balancing immunity and tolerance. Cell Death Differ. 2008, 15, 39-50.

52. Maestro, R.; Dei Tos, A.P.; Hamamori, Y.; Krasnokutsky, S.; Sartorelli, V.; Kedes, L.; Doglioni, C.; Beach, D.H.; Hannon, G.J. Twist is a potential oncogene that inhibits apoptosis. Genes Dev. 1999, 13, 2207-2217.

53. Valsesia-Wittmann, S.; Magdeleine, M.; Dupasquier, S.; Garin, E.; Jallas, A.C.; Combaret, V.; Krause, A.; Leissner, P.; Puisieux, A. Oncogenic cooperation between H-Twist and N-Myc overrides failsafe programs in cancer cells. Cancer Cell 2004, 6, 625-630.

54. Ansieau, S.; Bastid, J.; Doreau, A.; Morel, A.P.; Bouchet, B.P.; Thomas, C.; Fauvet, F.; Puisieux, I.; Doglioni, C.; Piccinin, S.; et al. Induction of EMT by twist proteins as a collateral effect of tumor-promoting inactivation of premature senescence. Cancer Cell 2008, 14, 79-89.

55. Cheng, G.Z.; Chan, J.; Wang, Q.; Zhang, W.; Sun, C.D.; Wang, L.H. Twist transcriptionally up-regulates AKT2 in breast cancer cells leading to increased migration, invasion, and resistance to paclitaxel. Cancer Res. 2007, 67, 1979-1987.

56. Mani, S.A.; Guo, W.; Liao, M.J.; Eaton, E.N.; Ayyanan, A.; Zhou, A.Y.; Brooks, M.; Reinhard, F.; Zhang, C.C.; Shipitsin, M.; et al. The epithelial-mesenchymal transition generates cells with properties of stem cells. Cell 2008, 133, 704-715.

57. Vesuna, F.; Lisok, A.; Kimble, B.; Raman, V. Twist modulates breast cancer stem cells by transcriptional regulation of CD24 expression. Neoplasia 2009, 11, 1318-1328.

58. Battula, V.L.; Evans, K.W.; Hollier, B.G.; Shi, Y.; Marini, F.C.; Ayyanan, A.; Wang, R.Y.; Brisken, C.; Guerra, R.; Andreeff, M.; et al. Epithelial-mesenchymal transition-derived cells exhibit multilineage differentiation potential similar to mesenchymal stem cells. Stem Cells $\mathbf{2 0 1 0}$, $28,1435-1445$.

59. Fu, J.; Qin, L.; He, T.; Qin, J.; Hong, J.; Wong, J.; Liao, L.; Xu, J. The Twist/Mi2/NuRD protein complex and its essential role in cancer metastasis. Cell Res. 2011, 21, 275-289.

60. Qin, L.; Liu, Z.; Chen, H.; Xu, J. The steroid receptor coactivator-1 regulates twist expression and promotes breast cancer metastasis. Cancer Res. 2009, 69, 3819-3827.

61. Vernon, A.E.; LaBonne, C. Tumor metastasis: A new twist on epithelial-mesenchymal transitions. Curr. Biol. 2004, 14, R719-R721.

62. Karreth, F.; Tuveson, D.A. Twist induces an epithelial-mesenchymal transition to facilitate tumor metastasis. Cancer Biol. Ther. 2004, 3, 1058-1059.

63. Yang, J.; Mani, S.A.; Weinberg, R.A. Exploring a new twist on tumor metastasis. Cancer Res. 2006, 66, 4549-4552.

64. Pan, P.Y.; Wang, G.X.; Yin, B.; Ozao, J.; Ku, T.; Divino, C.M.; Chen, S.H. Reversion of immune tolerance in advanced malignancy: Modulation of myeloid-derived suppressor cell development by blockade of stem-cell factor function. Blood 2008, 111, 219-228. 
65. Sinha, P.; Clements, V.K.; Fulton, A.M.; Ostrand-Rosenberg, S. Prostaglandin E2 promotes tumor progression by inducing myeloid-derived suppressor cells. Cancer Res. 2007, 67, 4507-4513.

66. Serafini, P.; Carbley, R.; Noonan, K.A.; Tan, G.; Bronte, V.; Borrello, I. High-dose granulocyte-macrophage colony-stimulating factor-producing vaccines impair the immune response through the recruitment of myeloid suppressor cells. Cancer Res. 2004, 64, 6337-6343.

67. Bunt, S.K.; Yang, L.; Sinha, P.; Clements, V.K.; Leips, J.; Ostrand-Rosenberg, S. Reduced inflammation in the tumor microenvironment delays the accumulation of myeloid-derived suppressor cells and limits tumor progression. Cancer Res. 2007, 67, 10019-10026.

68. Gabrilovich, D.; Ishida, T.; Oyama, T.; Ran, S.; Kravtsov, V.; Nadaf, S.; Carbone, D.P. Vascular endothelial growth factor inhibits the development of dendritic cells and dramatically affects the differentiation of multiple hematopoietic lineages in vivo. Blood 1998, 92, 4150-4166.

69. Kusmartsev, S.; Gabrilovich, D.I. STAT1 signaling regulates tumor-associated macrophage-mediated T cell deletion. J. Immunol. 2005, 174, 4880-4891.

70. Movahedi, K.; Guilliams, M.; van den Bossche, J.; van den Bergh, R.; Gysemans, C.; Beschin, A.; de Baetselier, P.; van Ginderachter, J.A. Identification of discrete tumor-induced myeloid-derived suppressor cell subpopulations with distinct $\mathrm{T}$ cell-suppressive activity. Blood 2008, 111, 4233-4244.

71. Terabe, M.; Matsui, S.; Park, J.M.; Mamura, M.; Noben-Trauth, N.; Donaldson, D.D.; Chen, W.; Wahl, S.M.; Ledbetter, S.; Pratt, B.; et al. Transforming growth factor-beta production and myeloid cells are an effector mechanism through which CD1d-restricted T cells block cytotoxic $\mathrm{T}$ lymphocyte-mediated tumor immunosurveillance: Abrogation prevents tumor recurrence. J. Exp. Med. 2003, 198, 1741-1752.

72. Ji, Q.; Hao, X.; Meng, Y.; Zhang, M.; Desano, J.; Fan, D.; Xu, L. Restoration of tumor suppressor miR-34 inhibits human p53-mutant gastric cancer tumorspheres. BMC Cancer 2008, 8, 266.

73. Chen, C.; Ridzon, D.A.; Broomer, A.J.; Zhou, Z.; Lee, D.H.; Nguyen, J.T.; Barbisin, M.; $\mathrm{Xu}$, N.L.; Mahuvakar, V.R.; Andersen, M.R.; et al. Real-time quantification of microRNAs by stem-loop RT-PCR. Nucleic Acids Res. 2005, 33, e179.

74. Ji, Q.; Hao, X.; Zhang, M.; Tang, W.; Yang, M.; Li, L.; Xiang, D.; Desano, J.T.; Bommer, G.T.; Fan, D.; et al. MicroRNA miR-34 inhibits human pancreatic cancer tumor-initiating cells. PLoS One 2009, 4, e6816.

(C) 2013 by the authors; licensee MDPI, Basel, Switzerland. This article is an open access article distributed under the terms and conditions of the Creative Commons Attribution license (http://creativecommons.org/licenses/by/3.0/). 